AGREGAT:Jurnal Ekonomi dan Bisnis

Vol. 3, No. 1, Maret 2019

http://journal.uhamka.ac.id/index.php/agregat

p-ISSN: 2549-5658 e-ISSN: 2549-7243

DOI: $10.22236 /$ agregat_vol3/is1pp35-45

Hal 35 - 45

\title{
ANALYSIS OF THE INDONESIAN FOREIGN TRADE POLICY WITH ARGENTINA IN PERIOD 2008-2013
}

\author{
Saefudin Zuhri, Habi Asyidiqi \\ Universitas Krisnadwipayana, Universitas Jayakarta \\ Email:ssaefudinzuhry@unkris.ac.id
}

Diterima: 24 Desember 2019; Direvisi: 7 Januari 2019; Disetujui: 10 Januari 2019

\begin{abstract}
This research aims to understand the reasons behind Indonesia trade with Argentina in the period 2008-2013. The formulation of the problem in this research is the "Why Indonesia keep doing trade with Argentina in the years 2008 to 2013 but the balance of trade deficit?". Through the frame of economic nationalism, the research found that in line with the value of a strong political history between the two, Indonesia had the interests of market access (trade policy) and strengthening of the domestic industry (industrial policy). Market access in this case related interests of Indonesia who made Argentina as a hub in the region of South America. But in terms of strengthening the domestic industry, not apart from the strengthening of the ranching industry needs through imports of animal feed from Argentina. Keywords: trade deficit, industrial policy, trade policy, economic nationalism, domestic industry

Abstrak

Penelitian ini bertujuan untuk mengetahui alasan di balik perdagangan Indonesia dengan Argentina pada periode 2008-2013. Rumusan masalah dalam penelitian ini adalah "Mengapa Indonesia tetap melakukan perdagangan dengan Argentina pada tahun 2008 hingga 2013 walaupun neraca perdagangan defisit?”. Melalui kerangka nasionalisme ekonomi, penelitian membuktikan bahwa sejalan dengan nilai sejarah politik yang kuat antara keduanya, Indonesia memiliki kepentingan akses pasar (kebijakan perdagangan) dan penguatan industri dalam negeri (kebijakan industri). Akses pasar dalam hal ini terkait kepentingan Indonesia yang menjadikan Argentina sebagai hubungan di kawasan Amerika Selatan. Namun dalam hal memperkuat industri dalam negeri, tidak terlepas dari penguatan kebutuhan industri peternakan melalui impor pakan ternak dari Argentina.
\end{abstract}

Kata Kunci : perdagangan defisit, kebijakan industry, kebijakan perdagangan, ekonomi nasional, industry domestik 


\section{INTRODUCTION}

Indonesia Trade cooperation with Argentina already lasted a long time. Agreement about economic cooperation and trade between the Governments of Argentina and the Government of Indonesia has already ratified on July 26, 1993, through Presidential Decree No. 67 the year 1993 in Jakarta. This relationship continues to evolve into a variety of sectors, such as tourism, health, banking, education, and investment (www. kemlu.go.id, 2008).

Since Indonesia trade agreement with Argentina in 1993 ratified, Indonesia has always suffered losses. Therefore, Indonesia export activities to Argentina are smaller compared to their import activities. Indonesia's exports are always ranked below than on their import. Although in a span of 1998 until the year 2003 experiencing heaving activities Indonesia trade exports and imports with Argentina, but did not affect overall trade that Indonesia has always been dominated by activities their import (www. comtrade.un.org, 2014).

Increased cooperation with Indonesia trading Argentina looks at the increasing volume of trade. There is a significant increase to the total trade of Indonesia and Argentina, look at table 1 below. In 2008, total trade in both countries just revolved around 800 million dollars, the United States (US) in the year 2013 increased significantly to two billion US dollars. Although in 2008 the trade conducted by the two countries is only done in the non-oil sector alone, over the next year to trade in the two countries to flourish not only in non-oil and gas sector but also in the oil \& gas sector of ten million US dollars in 2009.

Although total trade Indonesia and Argentina experienced a rise, on balance of trade experienced losses. In the Indonesia trade with Argentina in the years 2008 to 2013, Indonesia's import activities do more than with their export activities. In 2008 the value of exports carried out by Indonesia did not reach half of the total value of imports. The value of Indonesia's exports to Argentina just revolved around 187 million us dollars, while the value of imports amounting to 613 million US dollars. In the year 2013, the value of Indonesia's exports increased compared with the previous year, namely amounting to 335 million US dollars. v

Table 1.1.

Total trade in Indonesia and Argentina 2008-2013 Year (in thousands of US dollars)

\begin{tabular}{|c|c|c|c|c|c|c|}
\hline vescripuon & $\angle U O O$ & LUUY & $\angle 010$ & 2011 & 2012 & $\angle 015$ \\
\hline vescripuon & రUU.ठOU,J & $8 \angle J .1 J \angle, y$ & $1 . \angle \angle 0 . \angle 41,0$ & $1.940 .450,1$ & L.UOठ.ठ1/,0 & $\angle . U \angle 1.841,3$ \\
\hline I otal Irade & $\mathrm{U}, \mathrm{U}$ & $10 . J \angle 1,8$ & $3.951,1$ & $0.995,0$ & $0.1 \angle L, 4$ & $4 . / 2 /, y$ \\
\hline Ull and gas & סUU.ठ & $81 \angle .0 J 1,1$ & 1.LLL.JUY,Y & 1.95ग.44U,J & $\angle . U 0 \angle .0 Y J, L$ & L.U1/.UðJ,0 \\
\hline IVon-Uil and Gas & $18 / . U 20,0$ & IगY.UชY,I & $\angle X 1.1 \angle \angle, J$ & $504.4 / U, 4$ & $31<. J$ & 350.2 \\
\hline Export & $\mathrm{u}, \mathrm{U}$ & $u, U$ & $\mathrm{U}, \mathrm{U}$ & $1 / U, 4$ & $\angle 4, U$ & $u, u$ \\
\hline Uli and gas & $10 / . \cup 50,0$ & 1כy.uชy, I & $\angle O 1.1 \angle \angle, J$ & 354.30 & 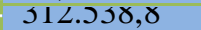 & .2 \\
\hline INon-Uil and & O15.85U,ग & $004.005,1$ & Y4ग.11Y,1 & 1.गఠग.У०ग, I & $1 . / 20 . \angle / 8,8$ & $1.080 .0 \angle 1,0$ \\
\hline import & $\mathrm{U}, \mathrm{U}$ & $1 U . J \angle 1,0$ & $3.931,1$ & $0 . \delta \angle J, L$ & 0. YYX,4 & $4.13 /, y$ \\
\hline Uil and gas & 015.85U,ว & $035.041,5$ & प्र4ग.18/,4 & 1.J/Y.14U,J & 1.IJU.18U,J & 1.0૪1.ర0У, 1 \\
\hline IVon-Uil and uas & $-4<0.14 /, 1$ & $-3 U 4 . Y / 5,4$ & -005.УY0,J & $-1.251 .4 Y J, 3$ & $-1.445 .139, y$ & $-1.501 .41<, 0$ \\
\hline Balance or trace & $\mathrm{U}, \mathrm{U}$ & $-10 . J<1,0$ & $-5.951,1$ & $-0.054, y$ & $-0.0 / 4, J$ & $-4.12 /, y$ \\
\hline U1l and gas & $-4<0.14 /, 1$ & $-494.431,0$ & $-000.004, y$ & $-1.2 \angle 4.84 U, 4$ & $-1.43 / .000,3$ & -1.540 .054 \\
\hline
\end{tabular}

Source: "Balance of Trade with Trade Partner Country",Central Bureau of Statistics (BPS)

and the Indonesian Ministry of Trade 
AGREGAT:JurnalEkonomidanBisnis

Vol. 3, No. 1, Maret 2019

http://journal.uhamka.ac.id/index.php/agregat

p-ISSN: 2549-5658 e-ISSN: 2549-7243

DOI: 10.22236/agregat_vol3/is1pp35-45

Hal 37

There are seven countries contributed to the non-oil trade deficit for Indonesia's largest in 2011-2013. The top three there is an adjacent country with Indonesia, namely Thailand, China, and Australia. Thailand and China are countries in the Asian region, while Australia directly adjacent on the lower part of Indonesia. In positions four and five there are countries that are on the American continent, namely, Argentina and Canada. Country Canada is a country located in North America, while Argentina is a country which is in the American South. Therefore, it makes Argentina as the South American country in the region that accounts for most of the trade deficit in the region (www.kemendag. go.id,2012).

Indonesia and Argentina trade barrier not only on the problems of a great distance but are also traded. Because of the two countries in developing countries, this means that the goods being traded are the result of farming such as vegetables, fruits, and nuts. Although it is not the main commodities traded goods. The main commodities traded by Indonesia in Argentina is rubber, vegetables, nuts, and protective footwear. While the main commodities traded by Argentina to Indonesia is a residue, waste from the food industry, animal food, vegetables and beans, cereals and cotton (www.komtrade.un.org).

Based on the above exposure, Indonesia still does trade with Argentina although the views of Indonesia trade balance suffered a loss or deficit. It has no effect with a total trade of Indonesia and Argentina that are experiencing continuous improvement each year. Even the trade barrier of Indonesia and Argentina is not just a deficit trade balance for Indonesia, but it is very long and also commodities traded. Based on the background, this research will try to analyze the reason what makes Indonesia keep doing trade with Argentina. Therefore, the problems in this research are Why Indonesia keep doing trade with Argentina in the years 2008 to 2013 but the balance of trade deficit?

The purpose of this research is to see the country in protecting the welfare of the nation, and also see a country's economic policies can affect the economic policies of other countries. Because this research focusses to Indonesia trade with Argentina which continue to trade despite the deficit on its trade balance. In addition, Indonesia trade with Argentina this is a cross-regional trade, that trade through a particular area to the other. Trading with Argentina that is part of the South American region can be an alternative market for Indonesia.

\section{Economic nationalism}

Economic nationalism to see that the State should be more worried about its national interests. Economic nationalism wants countries to shoulder the responsibility to enhance the ability of members of optimally in society, so that the achievement of a productive capability, at the same time cooperation between countries should also be more improved (Baehaqi Arif, 2016). Therefore, economic nationalism emphasizes the importance of promoting indigenous entrepreneurs, businesses and enhance the role of the State to establish a national industry(Kuncoro, 2013). 
Economic nationalism, based on the opinion of Otto Hieronymi(1980) is a complex phenomenon. Because of his thinking that goes beyond the traditional or non-traditional in trade issues, so this thinking allegedly complex. In economic nationalism, the State has always strived to protect the production in his country with all efforts including through efforts in policy or other barriers, dumping, export subsidies and various other trade policies Although detrimental for neighboring countries.

On various industrial policies in economic nationalism, as well as export or import policies on a voluntary basis, so that the occurrence of the development of the market economy in the country. Economic nationalism is not just limited to countries that are weak but also used by powerful countries, even small States and Liberals can only become a nationalist.

Although economic nationalism cannot be explained in a simple way, there are at least 3 definitions of analysis on economic nationalism. First, economic nationalism pursues national interests by sacrificing some national interests in order to achieve certain national goals. This was done so that it would benefit some citizens. Whereas the second definition contradicts the first definition, that sacrificing national interests in order to achieve certain national goals to benefit some groups, but by blurring facts so that their profits are seen as an advantage for all. Third, the most outstanding economic nationalism is pursuing national interests by sacrificing the interests of other countries(Hieronymi, 1980).
In this research, it used more economic nationalism in the first explanation, namely reaching national goals by sacrificing several other national interests. Based on the opinion of Henryk Szlajfer that economic nationalism has basic provisions. The entire economy must be oriented primarily towards supplying the domestic market and increasing the per capita income consumed. The export volume will depend on import requirements. Emphasis must be placed on increasing agricultural exports (Szlajfer, 1990).

In addition, Anthony P. D'Costa stated that Asian countries have been active in the industry, trade, investment, and technology policies with the aim of promoting and building a national economy. Economic nationalismisdefinedasseekingsustainability and new forms of economic nationalism which show that all forms of intervention from the state can be interpreted as a form of achieving national goals. However, forms of intervention in Asian countries have a firm economic foundation that aims to protect or promote national, industrial and economic business. After economic professionalism adapts to the global economy, it means that the state does not have a discriminatory policy but the state still supports domestic capital for business expansion.

Friedrich List states that economic nationalism based on protection carried out by a country is not permanent so that protection can be erased at any time. Then, the government can be expected to pursue new complementary policies which will be the initial form of new economic nationalism 
AGREGAT:JurnalEkonomidanBisnis

Vol. 3, No. 1, Maret 2019

http://journal.uhamka.ac.id/index.php/agregat

p-ISSN: 2549-5658 e-ISSN: 2549-7243

DOI: 10.22236/agregat_vol3/is1pp35-45

Hal 39

policy. The state also facilitates the process

conducted a literature study in collecting of adjusting to globalization through secondary data. The author collects various selective reforms and continues to protect domestic companies. The state pursues its economic goals both defensively and offensively, protects and promotes national assets and resources, both domestically and abroad(D'Costa, 2012).

Shivali Aggarwal asserted that Economic nationalism should be defined as a collection of policies whose results originate from a shared national identity or from the dominance of certain nationalisms in state politics. That is, economic nationalism must prioritize national interests over personal property and profit motives. Because economic nationalism is more than just trade protection and industrial policy. Economic nationalism is also the center of ideas of economic activities that must be subject to the country's development goals and the interests of the state (Aggarwal, 2016).

\section{RESEARCH METHODS}

This research uses qualitative research. During the research, researchers will collect data in the form of qualitative documents, both in the form of public documents and private documents. Public documents can come from newspapers, papers, or reports from government agencies such as the Ministry of Foreign Affairs and also the Ministry of Trade. Meanwhile, private documents can come from letters or e-mail (e-mail). The author also collects primary data from the official website of the Ministry of Foreign Affairs, Ministry of Trade, Ministry of Industry and also the Ministry of Agriculture. Furthermore, the authors written sources, such as books, literature, and academic journals. The author also considers the use of data collection techniques through in-depth interviews.

\section{Indonesian and Argentine Trade Relations}

In answering this research question, there are three reasons behind Indonesia's actions which continue to trade with Argentina even though Indonesia suffered losses in the trade. First, the historical value of politics between the two countries, Indonesia and Argentina. Second, Indonesia has an interest in expanding its market share in South America through Argentina. Third, Indonesia wants to protect the domestic livestock or agricultural industry.

a Historical Value of Politics

The relationship between Indonesia and Argentina is not only seen from the large value of trade between the two, but also from the historical value that has been going on for a long time.

After the proclamation of Indonesian independence in 1945, one of the Latin American countries that gave recognition to Indonesian independence at that time was Argentina (Feriolus Nawali, 2016). However, the new diplomatic relations between Indonesia and Argentina were inaugurated in 1956. This shows that the relationship between Indonesia and Argentina has a very important historical value for Indonesia because Indonesia's independence requires recognition from other countries.

After diplomatic relations between the Indonesian state and Argentina were 
formalized on June 30, 1956, relations between the two countries continued to run well. Indonesia's first visit to Argentina occurred when President Soekarno visited Argentina on the 21st May 1959. Likewise, Argentina visited the head of state, namely President Menem's visit in 1996, and President Fernandez de Kirchner in 2013.

On several visits, the President of Argentina produced agreements between Indonesia and Argentina. The first visit at the head of the state level by Argentina in 1996 conducted by President Menem, resulted in a Memorandum of Understanding (MoU) in cooperation in the field of animal health signed on August 26, 1996, in Jakarta (www. kemlu.go.id, 2016). During a visit by the head of state that took place in 2013 by the President of Argentina, Cristina Fernandez de Kirchner, it produced two MoUs that were related to investment promotion and cooperation in agriculture, as well as agreements in the field of transportation in this case related to flight opening or flight service (Doko, 2013).

Increasing cooperation relations between Indonesia and Argentina is not only seen from bilateral levels, but also at multilateral levels. There is three multilateral cooperation that can strengthen cooperation between Indonesia and Argentina, namely: Non-Aligned Movement (NAM), SouthSouth Cooperation, and FEALAC. The collaboration that continues to grow from time to time can also add to the sense of trust between Indonesia and Argentina.

These international institutions underlie as well as direct the activities of bilateral cooperation between Indonesia and Argentina. As for the economic goals of NAM, namely increasing world income by means of industrialization and agricultural technology cooperation to increase food production among developing countries (Departemen Luar Negeri, 1986). Then, South-South Cooperation as a reflection of solidarity which has a unique historical process among its members, South-South Cooperation has the aim of increasing the potential among its member countries (www. kemlu.go.id, 2014).

The main priority of NAM is the equality of nations and world peace in the system of economic and political relations in the world. There are two main attitudes in realizing this, first relying on self-reliance and national security of each country. Second, promote solidarity and cooperation between NAM countries to strengthen their position and increase their contribution in the preparation of the new international economic order. The NAM countries also have a strategy to campaign for a new international economic order, namely a combination of cooperation and mutual assistance in terms of better trade requirements for developing countries. This strategy aims to increase world income based on industrialization, agricultural modernization, independence in the field of technology and food production in developing countries 9 Ministry of Foreign Affairs(Departemen Luar Negeri, 1986).

Argentina has collaborated with Indonesia. Based on the statement of the Argentine Ambassador to Indonesia, Ricardo Luis Bocalandro, that Argentina 
AGREGAT:JurnalEkonomidanBisnis

Vol. 3, No. 1, Maret 2019

http://journal.uhamka.ac.id/index.php/agregat

p-ISSN: 2549-5658 e-ISSN: 2549-7243

DOI: 10.22236/agregat_vol3/is1pp35-45

Hal 41

has collaborated on food development technology, and Argentina also provides training on developing cattle farms in the East Nusa Tenggara region (www. kemlu.go.id, 2016). Because Argentina is the largest corn producing country in the region, and Argentina has implemented a modern agricultural scheme using certain technologies such as drones in its irrigation. Not only using technology, but also land that is well patterned (Miftahul Koer, 2016). Therefore, technological cooperation through technology transfer, especially in agriculture, is very beneficial for Indonesia, coupled with the training provided by Argentina.

In the framework of South-South Cooperation, Indonesia continues to develop cooperation with other developing countries such as Argentina. This aims to create a more just world economic order, such as the goal of NAM and South-South Cooperation, namely to form a new world economic order. Until finally, developing countries are no longer underestimated in the political system or the world economy (Brotodiningrat, 2012).

In 2014, Indonesia and Argentina supported each other in the United Nations organization. In the reform of members of the Security Council, Indonesia, and Argentina so that there will be no reform in permanent members, but the reform of the addition of members of the Security Council is only done to non-permanent members. Argentina also supports Indonesia serving again as a non-permanent member of the Security Council (Bora Asik, 2014 in www. milanmun.it). In the previous year, Indonesia also stated that it supported Argentina as a

non-permanent member of the Security

Council for the period 2013-2014.

b. Expansion of Market Share

Indonesia still directs its trade to traditional markets only. Until the 2008 crisis occurred the impact of the crisis that occurred in America (which is a traditional Indonesian market). Therefore, Indonesia should see alternative markets so that trade is not only focused on trading into traditional markets, but also extends markets to potential markets such as South America. The expansion of Indonesia's international trade market share is not only aimed at finding potential markets, but also aims at national development, trade promotion, and also the development of domestic industries.

The general objective of Indonesia's international trade policy is to increase access to export markets and facilitate exports. This is intended to reduce dependence on certain export markets, increase the growth of non-oil exports, diversify export markets, diversify export products, and improve the foreign trade business climate aimed at optimizing public services. The factors underlying the export policy are the fulfillment of domestic demand, namely consumption of industrial raw materials; Stability of domestic prices; and national food security and interests. Import policies are carried out to protect and increase farmers' income, stimulate the use of domestic production, make a trade and domestic market competitiveness and a conducive business (Ministry of Foreign Affairs Report in Tabloid Diplomasi, 2011).

Indonesia as a country that adheres to an open economic system, international trade 
especially exports is an important factor in driving economic growth. Indonesia's gross domestic product (GDP) of around 30\% comes from exports. Exports also make the domestic economy more passionate, because it will attract a lot of investment, employment, and utilization of local natural resources. The more products exported, will encourage economic growth in the country. The development of the world economy since entering the 21 st century has increasingly opened trade relations between countries, which is characterized by the increasing flow of goods and services between countries, despite the global crisis in late 2008 (Kementerian Luar Negeri Republik Indonesia, 2011).

c. Indonesia Protects the Livestock Industry The dependence of poultry feed on corn

from year to year is increasing as the population increases and national poultry production, there are no feed ingredients that can replace or substitute corn as a feed component which is considered more economical. Increasing national chicken meat and egg production also has an impact on increasing demand for animal feed. The Association of Animal Feed Entrepreneurs said that in 2011 national animal feed consumption is estimated to reach 10.3 million tons. This number increased $4.04 \%$ compared to 2010 which amounted to 9.9 million tons (www.industri.kontan.co.id, 2013).

As is well known, Indonesia experienced a trade deficit with Argentina. Based on data from the Ministry of Commerce of the Republic of Indonesia, the main goods imported by Indonesia from Argentina include cake, solid waste extracted from soybean oil, soybeans, broken or whole, and corn kernels (Kementerian Luar Negeri Republik Indonesia, 2015). This data is also reinforced by data on the United Nations Commodity Trade (UN Comtrade) that cake, soybean pulp, and corn are the top products in goods imported by Indonesia from Argentina. Even UN Comtrade said that for this product in 2012 it reached more than 1.5 billion US dollars. This explains that products such as cake, soybeans, and corn are very important for Indonesia because all these items are animal feed raw materials which have the highest nutritional content for poultry animals such as laying and broiler chickens, and ruminants such as beef cattle and pork (www.pse.litbang.pertanian.go.id, 2010).

In 2012, there was a trade deficit of US $\$ 23.59$ billion, which was then suppressed to US \$ 18.37 billion in 2013. The deficit was mainly due to a surge in imports of raw materials, auxiliary materials and capital goods. Of the total industrial product imports in 2012 worth US \$ 139.73 billion, around 90 percent of them were imports of raw materials, auxiliary materials, and capital goods. Imports in the same percentage occurred again in 2013. This means that industrial growth is directly proportional to the increase in imports of raw/auxiliary materials and capital goods.

The importation of the nine industry groups mentioned earlier comes from countries that have signed free trade agreements with Indonesia. Only in the food 
AGREGAT:JurnalEkonomidanBisnis

Vol. 3, No. 1, Maret 2019

http://journal.uhamka.ac.id/index.php/agregat

p-ISSN: 2549-5658 e-ISSN: 2549-7243

DOI: 10.22236/agregat_vol3/is1pp35-45

Hal 43

and animal feed industry and pulp and paper groups, the imports come from countries that do not have free trade agreements, namely Argentina, Canada, Brazil, and the United States (www.kemenperin.go.id, 2016).

Indonesia is required to import animal feed raw materials from cakes and corn so that domestic needs are met. Corn is one of the feed ingredients that should not be imported because domestic production has exceeded demand, it still has to be imported. This is due to the gap between production or supply and the needs of feed mills, especially those related to the accuracy of quality, quantity, and certainty of sustainable supply, including competitive prices. Corn imports are also experiencing difficulties because many countries require and use more competitive corn, such as feed ingredients, food, fuel, processed industrial raw materials, and fertilizer (Fertilizer). To meet these shortcomings or overcome these gaps must be met from imports.

\section{Trade Maintain Diplomacy Relations}

In the case of Indonesian trade with Argentina, which continues to trade even though it has a significant trade deficit in the period 2008-2013, it is not only due to the activities of Indonesia's imports from Argentina greater than its export activities. The reason Indonesia is continuing to trade with Argentina shows that there is a far more profound background behind this action. In this case, there is a deep interest that concerns Indonesia's trade with Argentina. The results of the research findings that have been described previously show three main reasons related to Indonesia's interests in

trade deficits with Argentina.

First, Indonesia's interest in its trade deficit with Argentina is to maintain the historical value of politics with Argentina. In this case, the reason Indonesia continues to trade with Argentina despite having a trade deficit, namely the position held by Argentina for Indonesia, and also the historical value possessed by the two countries that have important meaning and also affect the relationship between the two.

Second, Indonesia's trade with Argentina can also provide market expansion for Indonesia in the South American region. In the condition of the international system that is prone to crises such as the 2008 global crisis, coupled with the crisis that occurred in Europe, requires Indonesia to look for alternative markets in addition to its traditional market as well as this. The expansion of this market also has a purpose for Indonesia, which is among other things so as not to depend on one particular market; national development in the form of domestic economic growth by opening new markets will increase export activities; promotion of domestic products in destination countries such as Argentina; and also the development of domestic industries by meeting domestic needs.

Third, the trade deficit between Indonesia and Argentina aims to protect domestic industries related to livestock and agriculture. Another goal of Indonesia's trade with Argentina, namely Indonesia wants to maintain the livestock industry by importing animal feed raw materials so that domestic industries related to using raw 
materials such as cake, soybeans, and corn do not experience bankruptcy or even death.

\section{CONCLUSION}

The conclusion of this research is that trade deficits cannot only be seen in terms of exports and imports. Because trade itself is related to other sectors, such as development, industry and also some other interests besides economic interests. Indonesia's trade with Argentina, which has a deficit, has an interest in it, namely expanding Indonesia's international trade market share and also protecting the domestic livestock industry. All these things are also in line with the history of politics between Indonesia and Argentina.

\section{REFERENCE}

Aggarwal, Shivali. (2016). Economic Nationalism and Its Future Prospects: An Opinion. International Journal of Humanities and Social Sciences, ISSN 2250-3226 Vol. 6, No. 1, Research India Publication

Antara News. (2013). Indonesia-Argentina agree to Mutually Help at Multilateral Forums. Accessed on Januari 5, 2017, http://www.antaranews. $\mathrm{com} / \mathrm{en} / \mathrm{news} / 86916 /$ indonesiaargentina-agree-to-mutually-help-atmultilateral-forums.

Arif, Baehaqi. (2016). Globalcitizenship. Accessed on March 21, 2016, http://ppkn.uad.ac.id/wp--content/ uploads/4-Global-Citizen.pdf

Asik, Bora. (2014). Milanmun 2014: Reform of the Security Council. Accessed on January 5, 2017, http://www. milanmun.it/DATA/bacheca/file/ Anno2014/Bora.pdf.

Brotodiningrat, Soemadi. (April 2012). Grand Design Baru Kerjasama Selatan-Selatan. Tabloid Diplomasi: Media Komunikasi dan Interaksi, No. 54 Tahun V, Tgl. 15 April-14
AtikBudi Paryanti 44

Mei 2012, Kementrian Luar Negeri Republik Indonesia.

Comtrade. (2014). Indonesia - Top 10 Export of Goods to Argentina in 2014. Accessed on November 10, 2015.http://comtrade.un.org/labs/ BIS-trade-in-goods/?reporter $=360 \&$ partner $=32$ \&year $=2014 \&$ flow $=2$

D'Costa, Anthony P. (2012). Globalization and Economic Nationalism in Asia. United Kingdom: Oxford University Press.

Departemen Luar Negeri. (1986). Peran Indonesia sebagai Pendiri Gerakan Non Blok dalam Usaha Memurnikan Tujuan dan Prinsip-Prinsipnya. Jakarta: Departement of Foreign Affairs Research and Development Agency.

Doko. (2013). Indonesia-Argentina Tingkatkan hubungan Ekonomi. Harian Ekonomi Neraca. Accessed on February 24, 2016, http:// www.neraca.co.id/article/23983/ indonesia-argentina-tingkatkanhubungan-ekonomi.

Hieronymi, Otto. (1980). The New Economic Nationalism. London: The Macmillan Press.

Khoer, Miftahul. (2016). Soal Tanam Jagung Indonesia Harus Tiru Brasil dan Argentina. Harian Bisnis, diakses pada tanggal 02 Maret 2016 pukul 09:02 WIB, dari http://industri.bisnis. com/read/20160722/99/568159/soaltanam-jagung-indonesia-harus-tirubrasil-dan-argentina

Kontan News. (2013). Produsen Pakan Ternak Impor 2 Juta ton Jagung untuk Amankan Pasokan Bahan Baku. Diakses pada tanggal 11 Agustus 2016 pukul 7:30 WIB, dari http://industri.kontan.co.id/news/ produsen-pakan-ternak-impor-2juta-ton-jagung-untuk-amankanpasokan-bahan-baku-1. 
Hal 45

Kuncoro, Mudrajarad. (2013) Mengkaji Ulang Nasionalisme Ekonomi. Diakses pada tanggal 21 Maret 2016, pukul 12:30 WIB, dari https://www. academia.edu/4199297/Magazine_ mengkaji-ulang-nasionalismeekonomi

Ministry of Agriculture. (2010). Analisis Penawaran dan Permintaan Jagung untuk Pakan di Indonesia. Center for Agricultural Socio-Economics and Policy, Agricultural Research and Development Agency, accessed on Agustus 12, 2016, http://pse. litbang.pertanian.go.id/ind/pdffiles/ anjak_2010_01.pdf

Ministry of Foreign Affairs. (2008). Daftar Perjanjian Internasional Argentina. Accessed on November 9, 2015, http://www.kemlu.go.id/Daftar\%20 Perjanjian\%20Int erna siona l/ argentina.htm.

Ministry of Foreign Affairs. (2011). Peningkatan Peran Indonesia dalam Diplomasi Perdagangan Internasional. Tabloid Diplomasi, No. 41 Tahun IV, Tgl. 15 Maret-14 April 2011, Kementerian Luar Negeri Republik Indonesia.

Ministry of Foreign Affairs. (2014). Gerakan Non-Blok (GNB). accessed on Agustus 22, 2016, http://www. kemlu.go.id/id/kebijakan/kerjasamamultilateral/Pages/Gerakan-NonBlok.aspx

Ministry of Foreign Affairs. (2016). Argentina. accessed on April 8, 2016. http://www.kemlu.go.id/buenosaires/ id/Pages/Argentina.aspx.

Ministry of Industry. (2016). Statistik Industri Perkembangan Impor Indonesia Bardasarkan Sektor. Accessed on January,4,2017,http:// www.kemenperin.go.id/statistik/ peran.php.
Ministry of Law and Human Rights. (2013). Presidential Regulation of the Republic of Indonesia Number 13 of 2013. accessed on November 22, 2016, http://www.kemendagri.go.id. Ministry of Trade of Republic Indonesia. (2011). Kajian Kebijakan Pengembangan Diversifikasi Pasar dan Produk Ekspor. Ministry of Trade of the Republic of Indonesia, Kajian Kebijakan Pengembangan Diversifikasi Pasar dan Produk Ekspor, Trade Policy Assessment and Development Agency, (Center for Foreign Trade Policy,

Ministry of Trade of Republic Indonesia. (2012). Analisis Kinerja Perdagangan Indonesia Defisit Neraca Perdagangan. accessed on February 10, 2016, http:// www.kemendag.go.id/id/ news/2012/11/24/jakarta-analisiskinerja-perdagangan-indonesiadefisit-neraca-perdagangan-mei2012-dapat-ditekan

Nawali, Feriolus. (2016). Terbuka Peluang Tingkatkan Kerjasama Ekonomi RIArgentina. Republika Online, diakses pada 1 September 2016 pukul 1:16 WIB, dari http://www.rmol.co/ read/2016/02/14/235680/TerbukaPeluang-Tingkatkan-KerjasamaEkonomi-RI-Argentina-

Szlajfer, Henryk. (1990). Economic Nationalism in East-Central Europe and South America. Center of International Economic History: Geneva University 